\title{
MARGINAL FEAR OF DESPAIR AS AN EXPLICATION OF THE INTEGRITY OF CONSCIOUSNESS (CREATIVE COMPONENT)
}

\author{
Svitlana Martynova \\ Postgraduate Student, Donbas State Pedagogical University, Ukraine \\ e-mail: svetlana_marttyn@ukr.net,orcid.org/0000-0001-7981-7141 \\ Valeru Melnik \\ Ph.D., Professor, Donbas State Pedagogical University, Ukraine \\ e-mail: melnik-filosof1981@ukr.net, orcid.org/0000-0001-6028-4066 \\ Iwona Wojnowska \\ MA, Polonia University in Czestochowa, Interdisciplinary Faculty, Poland \\ e-mail: iwojnowska@ap.edu.pl, orcid.org/0000-0002-9004-2970
}

\begin{abstract}
Summary
The article considers the marginal fear of despair, which causes a vacuum in the soul as an explication of the anxiety of nothingness and uncontrolled fear of death are chains of a single process, symptoms of the «creative disease» of European culture. Unfortunately, modern culture rejects marginal fear as something superfluous, unnecessary to man, as something outdated and does not meet today's needs. Ironically, the first «bells» of secular culture began to sound in the late Middle Ages. As anxiety, it can destroy human life on an individual and social level. But in fact fear is necessary and cannot be completely eradicated. One must always balance between security and freedom, moving towards the other as a value. First, the main content of the methodological analysis of fear is one way or another, the metaphysical break of man with society, need or necessity. According to Protestant philosophers, the Fear of God (marginal fear) creates a set of religious and existential barriers that existentially prevent man from sin and evil, and at the same time it is the «beginning of wisdom», «the beginning of love», and even more so unites all believers in one common, consolidating and optimizing Fear. It was then that the accents began to change and in the face of death, man discovered the secret of his individuality. This connection shown by the Epicureans was long removed from the system of collective ideas and re-established in the minds of people only in the late Middle Ages. And since then individualism has influenced today's world. The anxiety of non-existence, which destroys the logocentrism of being and the fear of death as a logical consequence of this anxiety lead to the marginalization of man, his attempts to somehow justify his existence, which results in individual destructive forms such as suicide (when anxiety grows into despair) destructive forms: neo-fascism, extremism, racism (in case of substitution of the Absolute by quasi-absolute). It is clear that in this way a person, in a situation of lonely, alienated existence in the world, distracts himself with surrogates of meaning, avoiding feelings of anxiety.

Keywords: fear, marginal, creativity, death, loneliness, alienation, society.
\end{abstract}

DOI https://doi.org/10.23856/4115

\section{Introduction}

Cultural and philosophical analysis combines dialectical and synergetic methods in the study of marginal communities in culture as complex, open, dynamic, self-organized, holistic systems, the transformation of which is considered through the dialectical law of mutual transition of quantitative and qualitative changes. The method of extrapolation was used to 
identify indicators of the creative content of marginality. The constructive approach found its expression through the description of marginality as a social fact and its three-dimensionality. The use of an introspective approach has led to a vision of the marginal as if from within, the key concept for analysis in this case is «self-identification».

Today there is no general concept of marginality, there is no classification of its types and forms, there is no holistic rational concept, a universal explanatory model. Modern philosophy does not have adequate ways to solve the problem of marginality of the individual and society. The situation is exacerbated by the fact that in the XXI century in eastern Ukraine there is a war and people are on the verge of experiencing a transitional, «interparadigmatic» state: the system of values is collapsing, stereotypes are being broken. In the transition zone, such components of the worldview as God, the state, heroes, meaning, the real world, truth as conformity are deconstructed. There is nothing left but the worldview itself. Rational reality loses its meaning, I become absolute. The question of the anthropologization and ontologization of man in such a situation, the role of cognition as an attribute of the Self, the conditioned universality of the individual and his openness to the world becomes relevant. In our opinion, an epoch of a high level of instability is coming, which actualizes the problem of the stability of the human «I».

\section{The main text}

It is safe to say that the factor of marginality is especially evident with the growth of political and economic instability. This also applies to Ukraine at the turn of the 1990s and early 2000s where as a result of the crisis and reforms, previously stable social structures were destroyed, and the country in a process of transformation found itself in a state of marginal shock.

The aim of the article is to explore the creative and destructive component of sociocultural, religious marginality, its ontological origins, conceptual contradictions and fundamental worldview aspects.

The marginal reflecting consciousness which has experienced, at least once, the experience of being, one way or another comes to the conclusion that the fullness of being is only a kind of non-being, that being as an eternal escape is not endowed with essence. And what always remains as some necessary environment of consciousness, which cannot be destroyed and which cannot be avoided, is the loneliness of consciousness and anxiety before it. Marginal and metaphysical fear of the curse is an unmotivated, incomprehensible despair that arises from the fear of nothingness.

As soon as consciousness reveals its being as far as it understands it, it becomes hopelessly lonely; as much as it exists, as much as it is lonely. The living, existing consciousness is always a lonely consciousness that feels despair and anxiety before not being because of the sinfulness of human nature.

The marginal fear of the curse lies in human nature. She is metaphysically lonely and is in despair and on the verge. In Heidegger, loneliness and terrible homelessness is the meaning of human existence, its true existence. «The very structure of human consciousness is formed by deep and primordial loneliness.»

According to E. Husserl, loneliness is the main methodological requirement necessary for the implementation of transcendental reduction, which is the only way to comprehend the Ego in the act of removing the whole sensory-empirical world, people and the very overcoming of fear, curse and empirical self. This allows us to discover within consciousness the intersubjectivity of the Self, the ability of consciousness to perform an infinite number of its modes, the so-called transcendental Others. These can be past states of the Self, and memories of them that are experienced now, or the future Self, coexisting as a modification of the Ego. 
No one else can share my feelings and thoughts like myself, no one can experience my oneness for me. Each of my experiences is only my own, deeply individual process. In this sense, disunity is an essential condition of our experiences.

Loneliness can be marginally acute or dull, permanent or short-lived, inevitable or highly desirable, but always holistic, absolute, comprehensive and disturbing. I can't be half alone.

A person obsessed with loneliness loses the meaning and value of life. One has nothing to lose its connection with life if one has lost touch with others who were the meaning of this life.

One of the researchers of the phenomenon of loneliness, the existentialist Moustakas in his work «Loneliness and Love» emphasized the difference between «the vanity of loneliness» and «true loneliness.» The first is sporadically experienced by most people, taking it for granted; the second is metaphysical marginal loneliness, which is nothing more than the result of the realization of nothingness, the isolation of hopelessness and powerlessness associated with the understanding that all life connections in the form of interpersonal relationships are weakened and broken. The solitary consciousness perceives itself as homeless and vaguely abandoned, sad. Marginal loneliness forces the consciousness to bow to Nothing.

Loneliness locks the consciousness in a circle, frightens with the threat to break its intentional structure. The consciousness of a marginal person seeks to communicate with other «I» precisely because the presence of another is a mutual condition for the existence of my consciousness. To remove its orientation from the structure of marginal consciousness means to exclude self-consciousness. Anxiety is always strong because of the loss. And the greater the looming threat, the more intense the anxiety and fear are. Marginal loneliness frightens the loss of connection with being; it can be understood by consciousness as completeness, finiteness and doom to extinction. Moreover, «being lonely and isolated from others, one feels the fear of losing one's boundaries, of losing the ability to distinguish between the subjective self and the objective environment.»)

It is possible to overcome the fear of the curse by making a breakthrough, which is given only by love, when «Other» ceases to be «Other». «It is not this fear that separates him (man) from other people, but, on the contrary, his original isolation from them, his inability to love them, is the real cause of this fatal isolation - aloofness.»

However, in conditions when the «other» ceases to be «other», the consciousness again experiences the fear of losing its own «I», to dissolve into the «other», which has become «I».

Thus the fear of loneliness reveals one of the paradoxes of the existence of the consciousness of the marginal fear of the curse, which is that every moment of time it functions between two main poles: complete introversion and absolute openness; between the search for individuality, uniqueness. The desire to be oneself affirms the unique integrity of consciousness against the accidental and fleeting, against the universal non-existence of fragmented consciousness. But, having achieved this to some extent, the consciousness is suddenly terrified of absolute loneliness. And it goes back again, falling apart in relation to objective reality and convincing itself that it exists separately, but not alone.

«Fear not only reveals man in his hopeless loneliness, but enlightens man in terms of his demand for being, his ability to question the meaning of being as his own. The marginal fear of loneliness, as a sign of my self, tells me who I an».

In creative actions, marginal loneliness is necessary as a stage of centrifugal movement, as a means of self-knowledge and spiritual condensation of forces, a stage of constant evaluation and reassessment of actions and orientation, continuous value search, balancing on the verge of «change of destiny». In his ruthless psychoanalytically confessional diaries, Franz Kafka exposes the dichotomy of insurmountable, painful, and desirable loneliness. 
However, the artist's insurmountable desire for the full realization of creative potential and maximum embodiment breaks the vices of loneliness-evil, which is in collapse. The marginal artist, doubling the world, speaks to it through his objectifications - works, embodying in an individual art form his worldview, thus he doubles himself, dialogue with the world and people. The author is present in the author's language, in the images of the characters, in the reflection of artistic objects, «shining» through the text, as well as when the author goes into the shadows, silently contemplating his characters, coexisting with them in artistic reality.

The artist's duality includes the position of the addressee-reader, the listener, contained in a latent form in the worldview structures of the author's consciousness, as well as the position of the «addressee» (M. Bakhtin), whether Truth, God or other Supreme Meaning. Therefore, Homo Legens, a man who reads, is transported to the worlds born of life experience and artistic imagination of the author, is able to overcome the pressure of psychological loneliness, find support in the values of the author's philosophical and ideological concept and thus throw off the shackles of moral loneliness. At the same time, solitude-good remains necessary, but only if, firstly, there are full-fledged social connections, opportunities for self-development, and, secondly, there is no mental loneliness, but there is an internal psychological harmony of thoughts and feelings. If these conditions are not met, then we see a very clear desire to hide from the cruel, soulless social reality in the vast art worlds, almost innumerable in the long history of human civilization, containing hundreds of artistic experiments. Of course, one should not rely only on art as a panacea for marginal loneliness. M. Bakhtin warned against the «temptation of aesthetics», convincing due to the proximity of aesthetic existence to real life (greater proximity than in the theoretical world). In aesthetic life, you can only play a role in the mask of a double and a marginal. However, the doubling of the artist and the perceiver of the subject, the identification of the author with the reader, the viewer, the coincidence of the recipient's vision with the author's view, but only in the general main direction, the establishment of hidden, wordless dialogue between author and addressee combating loneliness-evil («bad loneliness») through loneliness-good, full doubling.

\section{Conclusion}

Thus, in cult worship, surrogate games, in creativity, clamped in the grip of alienation, the illusory psychological - and sometimes psychopathological - double is in the structures of consciousness of some pseudo-self subject and suppresses or displaces its activity to reality with its laws pathological deformed consciousness, distorting the true outlines of social reality. Hopeless loneliness seizes a person with a loss of hope - a bridge between the dim, sad present and the future, which contains the changed conditions in which a person is included in the image of an inner double - a psychological agent. And then full-fledged social ties are thinned, values are dimmed, and the inner self-portrait is detached from the subjective psychological structure in order to become a foreign role, a canon that is stuck tightly.

Only collective and individual Homo Faber can successfully resist multifaceted negative marginal loneliness, focused not so much on creating products of activity - objectification, capable of becoming fetishes hostile to people in a social bifurcation, but on creating interpersonal connections, communication, harmonious relationships. In the dichotomy I-Other communication is delineated by the phenomenological topics of individuals, lonely, by their very existence beings. I realize myself and become myself only by knowing my essence through, with the help, and, most importantly, for the Other - another «center» of unity. Regardless of the reason for the transition from one group to another, the marginal is in an intermediate status. 
He begins to doubt his value and significance, avoids new contacts because he is afraid of being rejected, not accepted. Predicts that he will fail in any endeavor. Fear of humiliation, shyness against the background of the loss of previous relationships leads to loneliness and isolation. The person delves into himself. The feeling of unfair treatment of the person sharpens that leads to negative perception of others and direct aggression.

\section{References}

Bakhtin M.M., Peshkov I.V. (1996) Ot filosofii postupka k ritorike postupka [From philosophy of action to rhetoric of action]. Moscow: Publishing house "Labyrinth». (in Russian)

Berezinska, O. V., (2018) Naukovi zapiski. Istoriya i teoriya kulturi. [Science Notes. History and theory of culture]. NaUKMA. Vol. 1. (in Ukrainian)

Gasanova, P.G., Omarova M.K. (2017) Psikhologiya odinochestva [The psychology of loneliness] Kiev: Limited Liability Company «Financial Rada of Ukraine». (in Ukrainian)

Gusserl, E. (1992) Krizis evropeyskikh nauk i transtsendentalnaya fenomenologiya. Vvedenie $v$ fenomenologicheskuyu filosofiyu [The crisis of European sciences and transcendental phenomenology. Introduction to phenomenological philosophy] Questions of Philosophy, no. 7. (in Russian)

Melnik, V. (2015) Fear of self-evident evidence in philosophical reflection [Fear of self-evident evidence in philosophical reflection] Visnik of Donbass State Pedagogical University. Series: Social and Philosophical Problems in the Development of People and Support. no. 3. pp. 59-65. (in Ukrainian)

Merton, R. (1966) Sotsialnaya struktura i anomiya [Social structure and anomie]. Sotsiologiya prestupnosti (Sovremennye burzhuaznye teorii) [Sociology of Crime (Modern Bourgeois Theories)]. Moscow: Publishing house «Progress». pp. 299-313. (in Russian)

Khaydegger M., (2013) Osnovnye ponyatiya metafiziki. Mir - konechnost - odinochestvo [Basic concepts of metaphysics. The world is finitude-loneliness]. Saint Petersburg: Vladimir Dal. (in Russian)

Shtompka, P. (2005) P. Sotsiologiya. Analiz sovremennogo obshchestva: [Sociology: Analysis of Modern Society] Moskow: Logos. (in Russian)

Yaspers, (1996) K. Sobranie sochineniy po psikhopatologii [Collected Works on Psychopathology]. In 2 Vol. Moskow: ed. center «Academy»; SPb .: White rabbit. (in Russian) 